\title{
Assessment of safety evacuation of persons in the design of assembly areas
}

\author{
P. Kucera \& E. Strakosova \\ Department of Fire Protection, Faculty of Safety Engineering, \\ VSB - Technical University of Ostrava, Czech Republic
}

\begin{abstract}
Fires and other emergencies in the premises of assembly areas (e.g. shopping centres) may have tragic consequences for persons and the environment. Current buildings are designed as construction objects that are larger and more complex than ever before, and therefore the range of potential disasters that may occur is much more diverse. Therefore, emphasis should be given on designing safe evacuation from these assembly areas in particular with regard to uneven distribution of persons in the building. The aim of the article is to present the simulation results of several variants of evacuation in a selected commercial centre with different densities of persons by the buildingEXODUS evacuation model and compare these with the current project regulations. There will also be assessed the potential impact of the negative effects of fire on the escaping persons.
\end{abstract}

Keywords: design, fire safety, assembly areas, evacuation, simulation.

\section{Introduction}

Shopping centres are as a major channel of selling currently on the rise and can be now seen as a certain standard of living due to their wide range of products. Persons spend there a relatively long time. The space in such a shopping centre is artfully laid out. Some premises also use irregular communication areas in order to keep customers inside as long as possible. Other attractions are of course various offers and discounts, which attract large numbers of persons.

Generally, the store is a subject whose extent of division is based on the range of goods and way of selling. In addition to department stores, which are the main 
type of retail network at the European level, there are also supermarkets, hypermarkets, mixed retail and other specialty stores.

For evacuation modelling using buildingEXODUS program a hypermarket was chosen as a model, where most of its premises are predominantly occupied by self-service areas, which sells not only food, but also non-food assortment with a floor area of over 5000 square meters.

\section{Significant factors affecting evacuation}

The course of evacuation is affected mainly by fire, which is accompanied by accompanying phenomena and it involves danger to persons. There are several main factors as heat, flames, smoke, toxic fumes rise and lack of oxygen. Among the most important factors that have a major impact on evacuation belong mental and physical condition of the individual. Safety of persons cannot be fully guaranteed because of the unreasonable behaviour that is caused by panic. One important factor is the layout of the building and the familiarity of the object for the persons. Therefore, it is necessary to provide correct marking of emergency exits to help people find their way to safety. A very important factor in assessing the movement of people in shopping centres is also uneven spatial distribution of persons.

\section{Methods for determining values of occupancy by persons}

In the Czech Republic, the principles determining occupancy by persons are treated in a technical standard CSN 730818 [1], and applies only to the

Table 1: Comparison of occupancy by persons in individual countries.

\begin{tabular}{|c|c|c|c|c|}
\hline $\begin{array}{l}\text { Type of } \\
\text { building }\end{array}$ & $\begin{array}{c}\text { Czech Republic } \\
{\left[\mathrm{m}^{2} / \text { person }\right]}\end{array}$ & $\begin{array}{c}\text { Germany } \\
{\left[\mathrm{m}^{2} / \text { person }\right]}\end{array}$ & $\begin{array}{l}\text { United States } \\
{\left[\mathrm{m}^{2} / \text { person }\right]}\end{array}$ & $\begin{array}{c}\text { New Zealand } \\
{\left[\mathrm{m}^{2} / \text { person }\right]}\end{array}$ \\
\hline Cinemas & $1.1 * *$ & $*$ & $*$ & $*$ \\
\hline Theatres & $1.1 * *$ & $*$ & $*$ & $*$ \\
\hline Libraries & 2.5 & 5 & 9.3 & 10 \\
\hline Offices & 5 & 5 & 9.3 & 10 \\
\hline $\begin{array}{l}\text { Schools - } \\
\text { classrooms }\end{array}$ & 1.5 & 2 & 1.9 & 2 \\
\hline $\begin{array}{l}\text { Schools - } \\
\text { laboratories }\end{array}$ & 2 & 5 & 4.6 & 5 \\
\hline Shops & $* * *$ & 10 & 2.8 & 3.33 \\
\hline Gyms & 4 & 5 & 4.6 & 2.85 \\
\hline Restaurants & 1.4 & 1.0 & 0.65 & 1.11 \\
\hline \multicolumn{5}{|c|}{$\begin{array}{l}\text { Note: } \quad * \text { The number of seats or beds. } \\
* * \text { Factor, which is multiplied by the number of persons referred to project. } \\
\text { **Area to } 50 \mathrm{~m}^{2}=1.5 \text {; next area from } 50 \text { to } 500 \mathrm{~m}^{2}=3.0 \text {; next area from } 500 \\
\text { to } 1500 \mathrm{~m}^{2}=5.0 \text {; next area above } 1500 \mathrm{~m}^{2}=10.0 \text {. }\end{array}$} \\
\hline
\end{tabular}


assessment of the building in terms of fire safety. Determining the number of persons that have to be evacuated from each assessed area will be based on standardized tabular values stated either in $\mathrm{m}^{2}$ per person, or according to the coefficient of the projected number of persons. There are similar requirements in distribution of persons in the building abroad [2-4], where the density of persons in the building depends on the size of the object under consideration (floor space) and the type of activity.

The comparative table of occupancy by persons in selected states shows that in the Czech Republic it is calculated for one person at least $1 \mathrm{~m}^{2}$ in almost all cases. It means that in the Czech Republic occupancies of the object are usually set higher.

\section{Real occupancy of persons in shopping centres}

The survey shows [5] that $45 \%$ of regular household purchases in the Czech Republic are done in supermarkets and $27 \%$ of Czech customers do their shopping in supermarkets. We tend to spend monthly average about 5 hours and 20 minutes in stores. As for the frequency of shopping, Czechs go shopping 10.2 times a month. The least number of customers occurs after opening stores or just before the closing time. The greatest onrush of customers is in the afternoon between 3 and $6 \mathrm{PM}$. Also various holidays can play a big role in density of occupancy by persons, when the number of persons increases up to two times.

All these factors contribute to determining occupancy of the premises. In some cases, there may be situations where the real occupancy of the object will reach higher values than the values projected according to CSN 730818 [1].

\section{Evacuation time}

Determination of the evacuation time is one of the traditional tools for designing escape routes. This period is the time interval during which all persons in the building should be evacuated, without being threatened by combustion products. Evacuation time is influenced by several parameters, which are expressed in the following equation [6]:

$$
t_{u}=\frac{0,75 \cdot l_{u}}{v_{u}}+\frac{E \cdot s}{K_{u} \cdot u}
$$

where $l_{\mathrm{u}}$ is escape path length [m]

$v_{\mathrm{u}} \quad$ movement speed $[\mathrm{m} / \mathrm{min}]$

$E \quad$ number of evacuated persons [persons]

$K_{\mathrm{u}} \quad$ unit emergency lane capacity [persons $/ \mathrm{min}$ ]

$u \quad$ number of escape bars [-]

$s \quad$ coefficient expressing the conditions of evacuation [-]

One limitation of this equation is that it does not allow a delay, but it is assumed that immediately after a fire follows an announcement of fire and then immediately comes evacuation. In practice, this course is not real. For a detailed 
assessment of evacuation can be considered the total time required to evacuate a building as the sum of consecutive time intervals - specifically, the detection time and an alarm setting, time to start evacuation and time for movement in the building. Generally, evacuation can be considered safe if the time required for evacuation is less than or equal to maximum available time for evacuation.

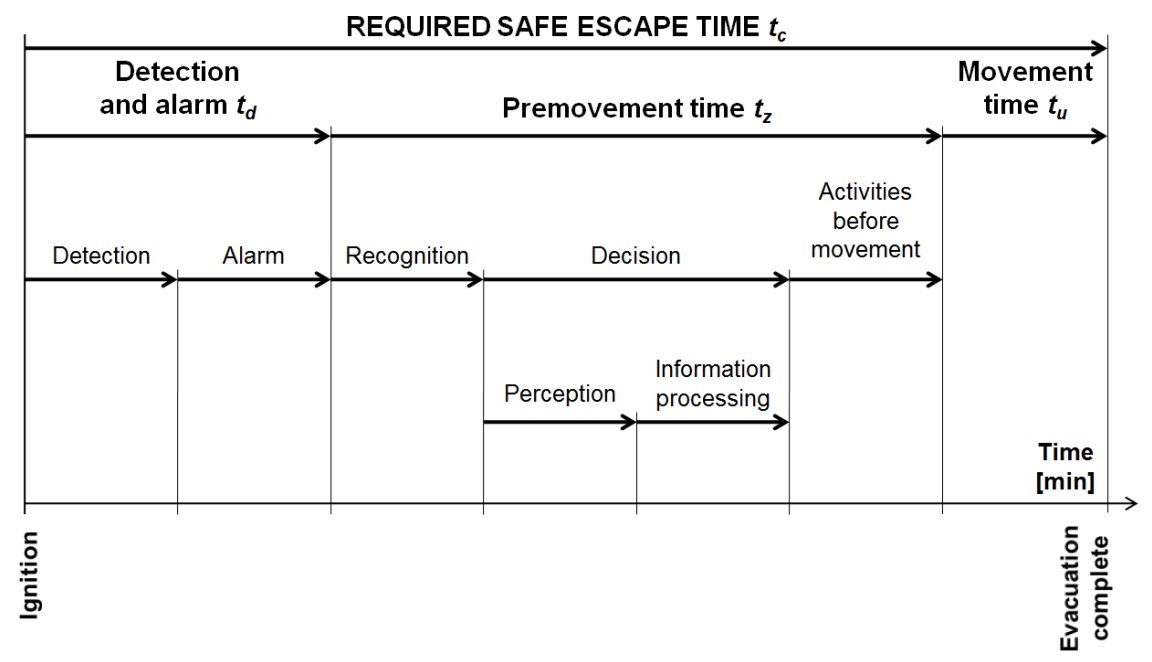

Figure 1: Required safe escape time (adapted from [7]).

\section{Description of buildingEXODUS evacuation model}

The BuildingEXODUS program [8] was created for use in the built-up environment and is suitable for simulation in supermarkets, hospitals, high-rise buildings, schools, etc. The behaviour and movement of each person is determined by a set of heuristic rules. These rules have been divided into five interacting sub models. These models are: the user occupant, movement, behaviour, toxicity and hazard. The vrEXODUS tool (Fig. 2) was made to help the interpretation of the results that serves as a postprocessor virtual reality enabling presentation of evacuation.

\section{Modelling evacuation in a hypermarket}

A single-storey hypermarket was selected with maximum ground plan dimensions of $81 \times 90 \mathrm{~m}$. Sales area with adjacent spaces consists of $5046 \mathrm{~m}^{2}$. Projected number of persons in this compartment is 2930.

The staff were deployed to places of their work. As the number of employees is less than 130 people, the staff on working shift is approximately 65 people. Values of the walking speed of the staff were chosen in the range from 0.9 to $1.35 \mathrm{~ms}^{-1}$ and a fast walking speed $1.5 \mathrm{~ms}^{-1}$. As for customers who are on the 


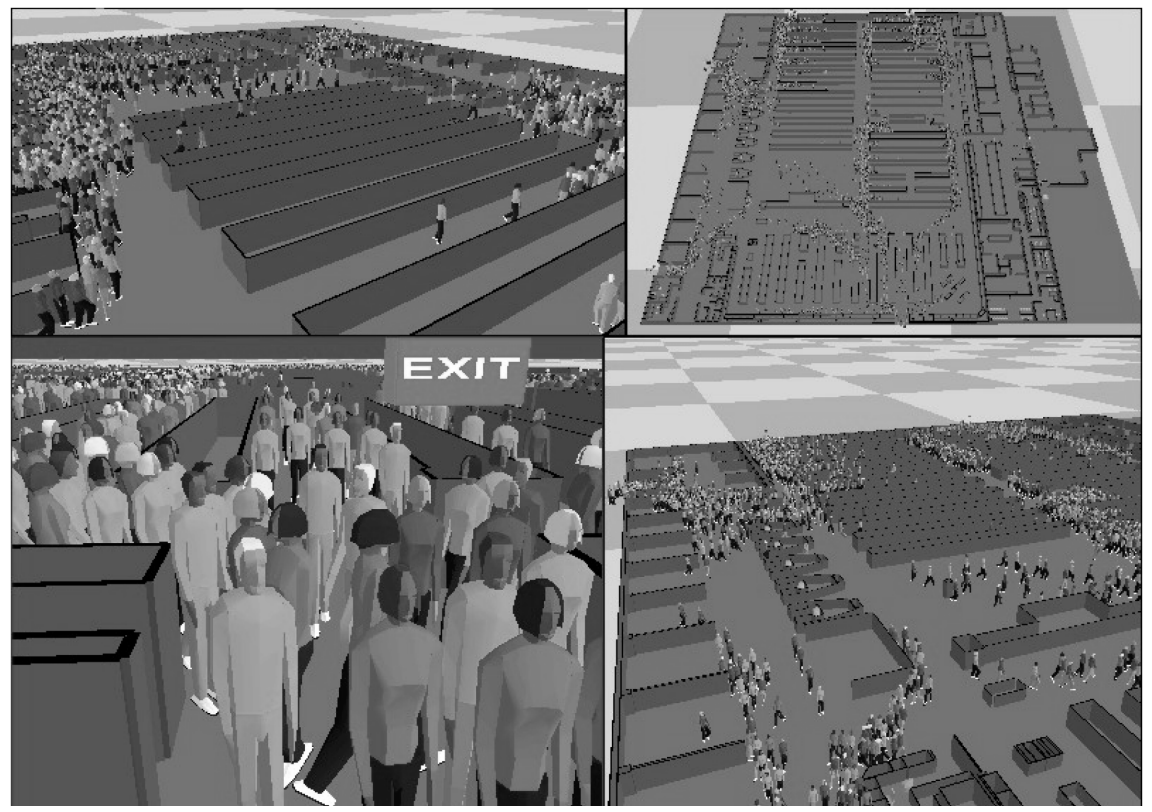

Figure 2: Virtual reality in buildingEXODUS.

surface of the hypermarket, shops and malls, their walking speed was reduced. The reason is that the persons take their shopping trolleys in most cases when leaving the object which of course reduces their movement speed. Most of them are also laden with their shopping goods or slowed down by shopping trolleys, whether empty on arrival or full when leaving. Both staff and shoppers were divided into 3 age groups, where each group had assigned walking speed and time delay. Persons react in case of an evacuation with a time delay, which better reflects the real situation. Since employees are better prepared for these situations, their time delay is shorter than in the case of the customers. Setting these parameters was carried out according to Table 2 .

Table 2: $\quad$ Parameters of the population in the simulation in a hypermarket.

\begin{tabular}{|c|c|c|c|}
\hline \multirow{3}{*}{ Population } & $\begin{array}{c}\text { Age group } \\
\text { [age] }\end{array}$ & $\begin{array}{c}\text { Time delay } \\
\text { [s] }\end{array}$ & $\begin{array}{c}\text { Speed of movement } \\
{\left[\mathbf{m . s}^{-\mathbf{1}} \text { ] }\right.}\end{array}$ \\
\hline \multirow{3}{*}{ Staff } & $17-29$ & $0-10$ & $0.9-1.35$ \\
\cline { 2 - 4 } & $30-50$ & $0-10$ & $0.9-1.35$ \\
\cline { 2 - 4 } & $51-80$ & $0-15$ & $0.81-1.215$ \\
\hline \multirow{3}{*}{ Customers } & $17-29$ & $0-30$ & $0.54-1.08$ \\
\cline { 2 - 4 } & $30-50$ & $0-30$ & $0.54-1.08$ \\
\cline { 2 - 4 } & $51-80$ & $15-30$ & $0.45-0.99$ \\
\hline
\end{tabular}




\section{Variant 1 - uniform distribution of persons according to standard}

The first alternative of the proposal is even distribution of persons in hypermarket. According to the standard [6] if two more escape routes lead to the fire compartment, then the limit capacity of escape routes is determined by the number of persons. In our case of 6 or more escape routes the number is $8-40 \%$ of persons. $40 \%$ of persons were assigned to the main exit, which would be the most used in the evacuation. Other side exits allow escape of $20 \%$ persons and the least used exits about $8 \%$.

During the simulation, persons react to the evacuation signal with a time delay. After $30 \mathrm{~s}$, however, all the persons are set in motion. Persons are gradually moving to the exits where queues are beginning to form. The main entrance and two side exits are most commonly used.

The number of persons who passed through the main entrance is the 2789 . The first person went through that door in time $4 \mathrm{~s}$, the last person at the time of $396 \mathrm{~s}$ from the beginning of the evacuation. The total simulation time is 6 minutes 36 seconds (396 seconds). The projected time is significantly shorter, 233 seconds.

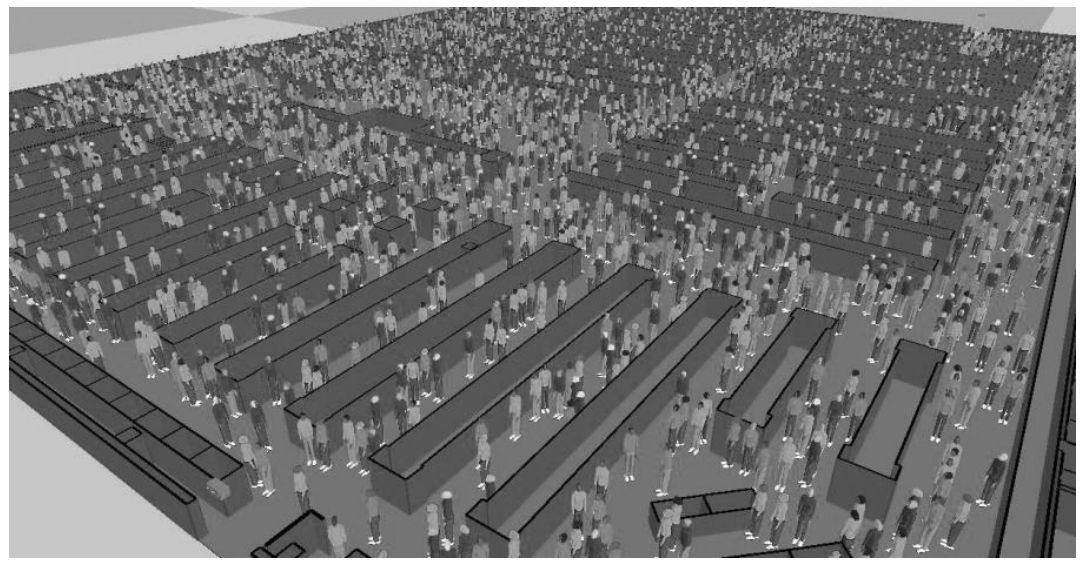

Figure 3: The density of persons at the beginning of the simulation with uniform distribution of persons.

\section{Variant 2 - uniform distribution of persons, equally utilized exits}

The second variant is an ideal situation of the uniform distribution of persons on the floor space who will use all exits with the same percentage of utilization.

Even at the beginning of the simulation we can observe a different way of escape, which is less disorganized with better used exits. In reality, however, this option is not very likely. Length of the simulation is shorter than in the previous variant and it is of 5 minutes and 43 seconds (343 seconds).

\section{Variant 3 - uneven distribution of persons with uniformly used exits}

The third variant is the uneven distribution of persons in the building, which corresponds better to reality and was determined according to the results of 
observation. Most of the persons were placed next to shelves containing foods and to major corridors of the hypermarket, for our case two thirds of the total number of persons (1924). The remaining third was deployed into a non-food department.

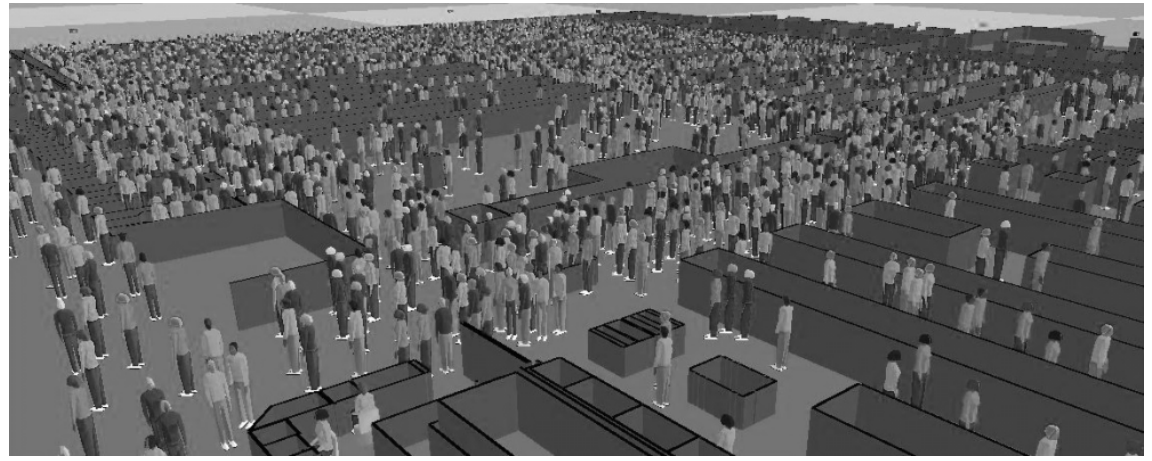

Figure 4: The density of persons at the beginning of the simulation in the case of the uneven distribution of persons.

Since there is an uneven distribution of persons, the evacuation itself is not even where the same potential is considered for all exit doors. Queues are expected to form at the exit, where is the highest density of persons.

The total simulation time is 6 minutes and 44 seconds (404 seconds). The time is about a minute longer than in the same setting of throughput in Variant 1 (with a uniform distribution of people).

\section{Variant 4 - uneven distribution of persons unequally used exits}

The fourth variant is the closest to the real situation. Uneven distribution of persons means also unevenly utilized exits. They, therefore, as in the case of the first variant, were set so that the main exit will allow escape of $40 \%$ of all persons while through the side exits get away about $20 \%$ of persons and less exploited exits will allow escape of $8 \%$ persons. The total simulation time is 7 minutes and 10 seconds (430 seconds).

\section{Variant 5 - uneven distribution of persons, uniformly used exits, fire hazard influence}

The fifth variant simulates an evacuation during fire. The fire was simulated using CFast [9], which was inserted in to the buildingExodus. Distribution of persons is again uneven and attractiveness of the exits is adapted according to the fire location. In this variant, the fire hazard was defined by the scenario mode. Human behaviour is affected by another feature, which is the extreme behaviour during the fire. The total length of the simulation is 7 minutes and 44 seconds. Evacuation time is longer than in the previous versions. This is mainly due to less used main exit and its replacement by other exits away from the fire. 


\section{Comparison of different variants of evacuation}

Most realistic conditions, which may take place during an evacuation, are simulated in the last variant. There is the longest evacuation time (464 seconds). In contrast, in case of the most ideal conditions simulated in variant 2 , there is the shortest evacuation time (343 s). However, all simulated results using buildingEXODUS last longer than the calculation made under the design requirements. One of the reasons is that the design standards expect uniform placement of persons on the whole area, which however hardly occurs in reality, as more persons tend to accumulate in certain departments. Another reason is the delay in the reaction of persons to announcement of evacuation with which is not considered in the design standards. Also speed of movement has significant effect on the time of evacuation. The speed is mainly influenced by the fact that persons after an announcement of alarm tend to take with them their shopping trolleys, thereby reducing their own movement speed, or leave them in place, which creates artificial barriers to others.

Table 3: Comparison of the particular simulations of evacuation options in the hypermarket.

\begin{tabular}{|c|c|c|c|}
\hline & Time [min] & [s] & Notes \\
\hline $\begin{array}{c}\text { Projected } \\
\text { (equation } \\
\text { 1) }\end{array}$ & $\begin{array}{c}3 \text { minutes } \\
53 \text { seconds }\end{array}$ & 233 & $\begin{array}{c}\text { time delay before the evacuation } \\
\text { not considered }\end{array}$ \\
\hline Variant 1 & $\begin{array}{c}6 \text { minutes } \\
36 \text { seconds }\end{array}$ & 396 & $\begin{array}{c}\text { even distribution of persons } \\
\text { according to CSN 73 0802 [6] }\end{array}$ \\
\hline Variant 2 & $\begin{array}{c}5 \text { minutes } \\
43 \text { seconds }\end{array}$ & 343 & $\begin{array}{c}\text { even distribution of persons, } \\
\text { uniformly used exits }\end{array}$ \\
\hline Variant 3 & $\begin{array}{c}6 \text { minutes } \\
44 \text { seconds }\end{array}$ & 404 & $\begin{array}{c}\text { uneven distribution of persons, } \\
\text { uniformly used exits }\end{array}$ \\
\hline Variant 4 & $\begin{array}{c}7 \text { minutes } \\
10 \text { seconds }\end{array}$ & 430 & $\begin{array}{c}\text { uneven distribution of persons, } \\
\text { unequally recovered exits }\end{array}$ \\
\hline Variant 5 & $\begin{array}{c}7 \text { minutes } \\
44 \text { seconds }\end{array}$ & 464 & $\begin{array}{c}\text { uneven distribution of persons, } \\
\text { uniformly used exits, fire hazard } \\
\text { influence }\end{array}$ \\
\hline
\end{tabular}

\section{Comparison of evacuation model results with design rules}

All simulated results using buildingEXODUS have longer time of evacuation than the calculation according to the project technical standards. There are several reasons for that. The first reason is that the design rules allow only uniform placement of persons in the surface. The authors of this article consider this problem as the most serious, and the one that influences the evacuation the most. In reality certain departments contain the greater number of persons than 

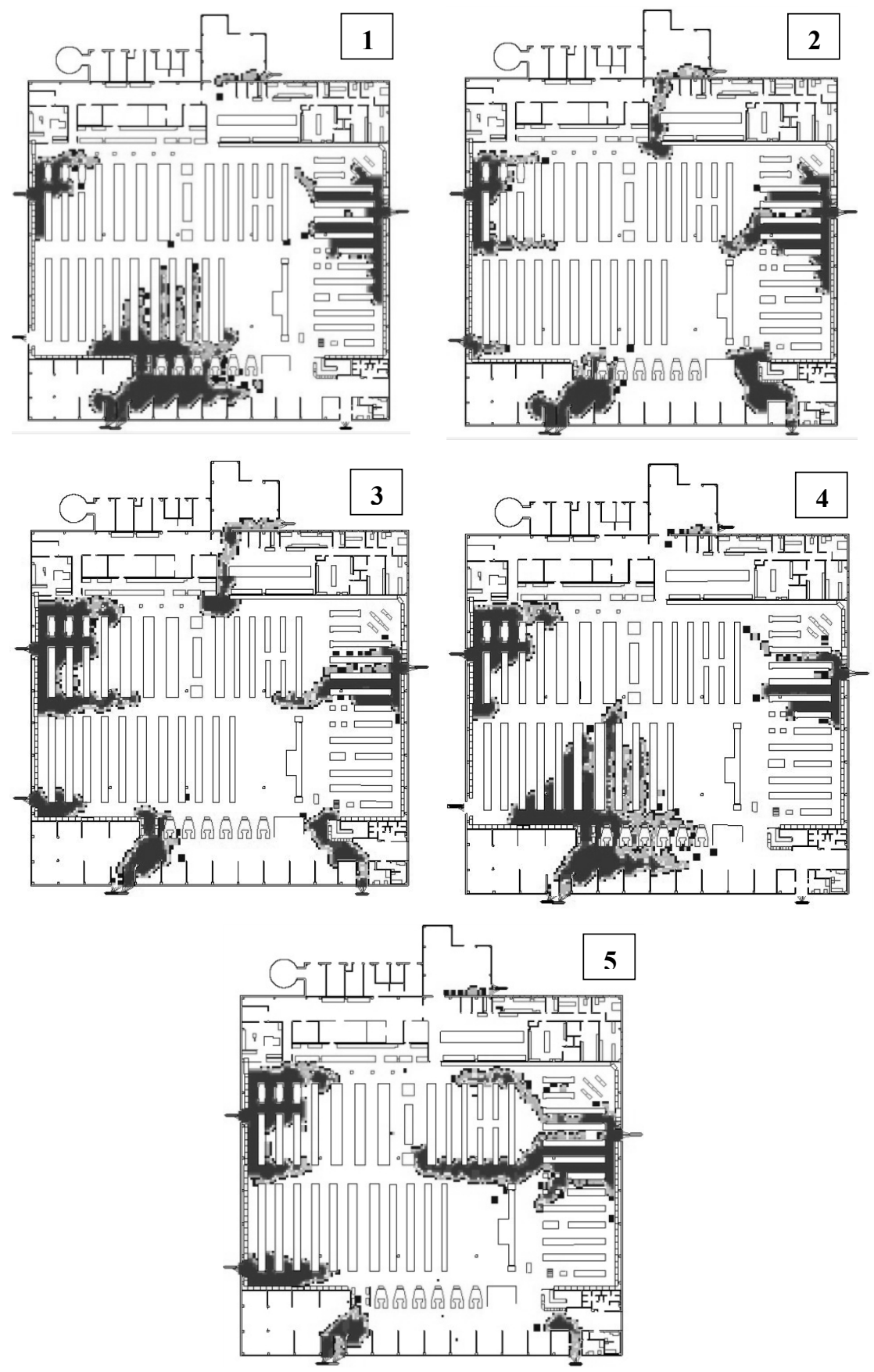

Figure 5: The comparison of different variants of evacuation in the first minute. 
others. There are always more persons next to shelves containing the food than for example at a clothing department. This fact is also based on the assumption that persons will escape to the nearest exit and the use of escape exits should therefore not be too uneven. In practice, however, most persons are coming back to the main exit. The project regulations do not consider these options. Distribution of persons is even, the values are averaged and the result is therefore hardly similar to reality.

Another reason is the delay in the reaction of persons to evacuate announcement. According to the rules, the persons at the time of the evacuation respond immediately and a delay is not taken into account. In particular, customers have to realize first what is happening around them, they are supposed to think how they should behave and they subsequently decide to leave the area. Determination of the reaction is relatively difficult, because there are too many aspects that may influence the final time. We cannot, however, neglect that. The buildingEXODUS program allows us to set response time by changing the properties of persons and thus to get the simulation closer to reality.

Also speed movement has significant effect on the time of evacuation. In hypermarkets it is mainly influenced by the fact that, after alarm, customers will be likely to take their shopping trolleys with them, which will reduce their movement speed. The slowdown may also occur if they leave their trolleys on the site, and they will create artificial barriers. The biggest barrier of evacuation will most likely pose trolleys left in the escape route at cashiers' desks.

\section{Conclusion}

The number of buildings with the accumulation of a large number of persons is increasing. It increases the risk of serious emergencies. Therefore, it is necessary to create conditions for rapid and safe evacuation. There is a need to constantly update the already proven commercial standards and this way to adapt better to contemporary state of affairs using the latest programs.

\section{Acknowledgement}

This work was supported by the project of the Ministry of the Interior of the Czech Republic No. VG 20122014074 - "Specific Assessment of High Risk Conditions for Fire Safety by Fire Engineering Procedures".

\section{References}

[1] ČSN 730818: Požárnibezpečnoststaveb - Obsazeniobjektůosobami [Fire protection of buildings - Person/surface rate in buildings]. Praha: Českýnormalizačníinstitut, 1997.

[2] LeitfadenIngenieurmethoden des Brandschutzen. TechnisherBericht. Atlenberge: VereinigungzurFörderung des DeutschenBrandschutzes, 2009. 
[3] NFPA 101: Life Safety Code. National Fire Protection Association, Massachusetts, USA, 2009.

[4] The Building Act 2004 (A2004-11), ACT Parliamentary Counsel, New Zealand, 2012.

[5] RÖSZLEROVÁ. Češiměsíčněpodniknouprůměrně 10 nákupů a vyrážejíhlavně do supermarketů. Retail Info Plus [online]. 2010 [cit. 201304-01]. Available from: http://www.retailinfo.cz/magazin/clanky/cesimesicne-podniknou-prumerne-10-nakupu-vyrazeji-hlavne-do-supermarketu

[6] ČSN 730802. Požárníbezpečnoststaveb - Nevýrobníobjekty[Fire protection of buildings - Non-industrial buildings]. Praha: Úřad pro technickounormalizaci, metrologii a státnízkušebnictví, 2009.

[7] PROULX, G.: Evacuation Time. DiNENNO, P.J. (Editor). The SFPE Handbook of Fire Protection Engineering. Quincy: National Fire Protection Association, Chapter 3-12, 2008. ISBN 978-0-87765-821-4.

[8] GALEA, E.R. et al. buildingEXODUS V5.0 - User Guide and Technical Manual. University of Greenwich, London, 2011.

[9] PEACOCK, R. et al. CFAST - Consolidated Model of Fire Growth and Smoke Transport (Version 6) - User's Guide. National Institute of Standards and Technology, Special Publication 1041r1. Washington, 2013. 